\title{
УДК: 368
}

JEL Classification: L860

\author{
(C) Кисільова І. Ю., Геворгян Г. А., 2020 \\ i_yu_kisileva@ukr.net, unicornuniuni1@gmail.com \\ Запорізький національний університет, Запоріжжя
}

\section{ФУНКЦІОНУВАННЯ ІНФОРМАЦІЙНИХ СИСТЕМ І ТЕХНОЛОГІЙ У СТРАХУВАННІ}

\begin{abstract}
Розглянуто поняття «інформаџійні системи», «інформаційні технологї», проаналізовано найбільш актуальні інформаційні системи, щуо наразі використовуються страховими компаніями України. Оглянено $і$ проаналізовано інформаџійні системи України задля пропонування більи ефективних видів інформаційних систем і поліпшення стану страхового ринку краӥни в цілому та діяльності страхових компаній.
\end{abstract}

Ключові слова: інформаційні системи, технологія, страхування, страхова компанія, страховик, страхувальник.

Постановка проблеми. Розвиток страхової діяльності в Україні тісно взаємопов'язаний із розвитком i впровадженням інформаційних систем у діяльність страхових компаній. Такі системи $є$ засобом комунікації між страховиками, посередниками та страхувальниками.

Страхування - один із найбільш інформаційно насичених та інформаційно залежних видів економічної діяльності. Факт того, що Україна продовжує розвиватися та наближатися до світових стандартів страхування, - це збільшення вимог до об'єктивної оцінки фінансового стану підприємств, що змушує страхові компанії застосовувати автоматизовані інформаційні системи та технології.

У сучасних економічних умовах страхові компанії продовжують стрімко розвиватися. У страховій сфері зростає клієнтська база, загострюється конкуренція, виникає необхідність введення нових послуг (а в умовах карантину - ще й Інтернет - послуг) - і усе це диктує необхідність введення інформаційних систем та опору на сучасні інноваційні технології.

Також зауважимо, що страхування - це досить складний за структурою та діяльністю процес, що також $\epsilon$ причиною створення страховими компаніями інформаційних систем.

Відповідно до тлумачного словника, інформаційна система - це система, що здійснює пошук, збирання, зберігання, опрацювання та передачу інформації. А отже, оцінювати ефективність інформаційної системи варто за вищезазначеними критеріями.

Аналіз останніх досліджень і публікацій. Суть діяльності інформаційних систем i технологій, огляд і аналіз таких систем у сфері страхування вивчали багато зарубіжних i вітчизняних дослідників. Зокрема, О. В. Грицунов досліджував інформаційні системи в цілому, а не тільки їх використання в страховій діяльності. Він увів класифікацію інформаційних систем для різних видів економічної діяльності, пояснив різницю між інформаційними системами та технологіями в різноманітних економічних видах діяльності [1].

У контексті розглянутого в цій статті питання варто приділити увагу праці I. Б. Шевчука, який проаналізував CRM - системи, що просуваються сьогодні постачальниками України, виділив та порівняв їх між собою [2]. У праці Павленко П. М., Філоненко С. Ф. та Бабіч К. С. висвітлено комплексний аналіз сучасних інформаційних технологій [3], а I. О. Ушакова та Г. О. Плеханова докладно виклали характеристики корпоративних інформаційних систем, їх класифікації, критерії та методи вибору, проблеми інтеграції та створення єдиного інформаційного простору[4]. О.В. Нєізвєстна й А. О. Огоновська розкрили значення інформаційного забезпечення в системі менеджменту страхової діяльності, визначили специфіку процесу підготовки інформації для використання в системі страхового менеджменту й основні вимоги до якості інформації, яка використовується у процесі управління страховою діяльністю [5].

Тобто, вищевказані вчені досліджували поняття «інформаційні системи та технології», аналізували діяльність таких систем на підприємстві, а також у деяких працях було проаналізовано стан інформаційних систем саме у страхових компаніях.

Виділення не розв'язаних раніше частин загальної проблеми. Незважаючи на значні дослідження в обраній нами темі багатьма дослідниками, все ж залишаються нерозв'язані питання, а саме: яка інформаційна система $\epsilon$ найбільш універсальна для страхової компанії; які проблеми існують у сфері використання інформаційних систем і технологій на ринку страхових послуг; які методи поліпшення роботи страховиків за допомогою інформаційних систем існують узагалі? Глибокий та детальний аналіз цього питання дасть змогу зрозуміти, які саме інформаційні системи вводити в діяльність 
страхових компаній та як поліпшити процес надання страхових послуг клієнтам.

Формулювання цілей статті. У ході даного дослідження авторами передбачено постановку таких цілей та завдань $\mathrm{i}$ вирішення таких наукових питань: визначення та конкретизація поняття «інформаційна система та технологія»; визначення критеріїв оцінки інформаційної системи задля аналізу іiі в подальшому; аналіз та оцінка стану функціонування інформаційних систем i технологій на сучасному етапі функціонування страхових фірм; пропонування можливих методів поліпшення роботи страхових компаній шляхом удосконалення діючих інформаційних систем.

Виклад результатів дослідження. Першим кроком даної роботи вважаємо за необхідне виокремити та проаналізувати два значущих понятт: «інформаційна система» та «інформаційна технологія», оскільки різні автори по-різному трактують ці поняття.

Отже, інформаційна технологія (IT) - це сукупність методів, виробничих процесів i програмно-технічних засобів, об'єднаних у технологічний ланцюжок, що забезпечує збір, обробку, зберігання, поширення й відображення інформації 3 метою зниження трудомісткості процесів використання інформаційного ресурсу, а також підвищення його надійності й оперативності [3].

Проаналізувавши тлумачення 3 кількох джерел, нами складено Таблицю 1, в якій ми виокремили тлумачення «інформаційна система» кількома вченими.

\section{Визначення терміну «Інформаційна система» різними вченими}

\begin{tabular}{|l|l|}
\hline ПІБ вченого & \multicolumn{1}{c|}{ Тлумачення } \\
\hline Грицунов О. В. & $\begin{array}{l}\text { Інформаційна система - це сукупність внутрішніх і зовнішніх потоків прямого і } \\
\text { зворотного інформаційного зв'язку певних об'єктів, засобів, фахівців, що беруть } \\
\text { участь у процесі обробки інформації та виробленні управлінських рішень [1]. }\end{array}$ \\
\hline Шевчук І. Б. & $\begin{array}{l}\text { Інформаційна система - комунікаційна система, що забезпечує збирання, } \\
\text { пошук, оброблення та пересилання інформації [2]. }\end{array}$ \\
\hline $\begin{array}{l}\text { Казимир В.В., Тесля } \\
\text { Ю. М., Стасюк О. I. }\end{array}$ & $\begin{array}{l}\text { Інформаційна система є середовищем, структурними елементами якого є } \\
\text { програмні та апаратні засоби маніпулювання інформацією, мережі, Бд, людина, } \\
\text { засоби зв’язку та ін. Основне завдання IC - організація, обробка, зберігання, } \\
\text { подання та передавання інформації [3]. }\end{array}$ \\
\hline
\end{tabular}

*Джерело: розроблено авторами на основі [1], [2], [3].

Отже, виходячи 3 вищевказаних трактувань, можемо дати власне визначення даного поняття: Інформаційна система - це складна система (середовище), структурними елементами якої $\epsilon$ інформація, людина, засоби комунікації тощо, а основними функціями - обробка, зберігання, подання та передача значних потоків інформації, допомога у прийнятті управлінських рішень.

Перш ніж вводити у діяльність страхової компанії інформаційні системи, перш за все необхідно налагодити саму діяльність компанії: усі робочі процеси повинні бути ретельно налагоджені, документально оформлені у вигляді правил та інструкцій, має бути обдумано, хто і як підписує поліси від імені компанії, як проводяться розрахунки з брокерами тощо. Якщо таке налагодження роботи компанії проведено не було, то розробка ефективної інформаційної системи практично неможлива.

Базові вимоги до установки автоматизованої інформаційної системи у страхуванні визначаються специфікою бізнесу і $є$ такими:

- єдиний інформаційний простір для всіх модулів системи;

- достатня швидкість для роботи з широкою базою даних;
- гнучкість i відкритість системи (це необхідно для легкого та швидкого налаштування системи при, наприклад, зміни законодавства);

- висока надійність і безпека зберігання даних;

- можливість нарощувати потужність;

- оперативність і підтримка розподіленої роботи;

- масштабованість [6].

Основні переваги впровадження інформаційної системи в діяльність страхових фірм такі: легкість контролю за діяльністю фірми, усунення необхідності в зберіганні паперових документів, працівникам компанії легше проводити різні розрахунки (стосовно визначення тарифів страхування, розрахунок страхових сум i платежів тощо) [7].

Спершу зазначимо, що існують різні види інформаційних систем страхової діяльності:

1. Автономні автоматизовані робочі місця (APM).

2. Комплекс взаємопов'язаних АРМ, що функціонують на єдиній інформаційній базі.

3. Корпоративна інформаційна система страхової діяльності. 
У страховій діяльності також використовують бази даних (БД), які відрізняються залежно від масштабів страхових компаній. Існують локальні БД, мережева БД, розподілена БД і централізовано зберігається БД на окремому комп'ютері, на якому встановлено АРМ страхового агента [9].

До програмного забезпечення страхового бізнесу належать такі програми: 1C: Підприємство 8. Страхова компанія 8 КОРП, IBS Insurance, АДС: Управління центром страхування 8, Master Insurance, SaM Solutions 6, Парус Страхування та інші.

На підставі відгуків і згадок на сайтах у сфері страхового бізнесу найбільш популярні сьогодні саме комплексні програми, такі як «Парусстрахування», «1С: Підприємство 8. Страхова компанія 8 КОРП» $\mathrm{i}$ «АДС: Управління центром страхування 8 » [8]. В межах цього дослідження будемо аналізувати вищезгадані найбільш поширені системи.

Розпочнемо з «1С: Підприємство 8. Страхова компанія 8 КОРП». Цей програмний продукт призначений для комплексної автоматизації діяльності страхових компаній, котра включає в собі бухгалтерський облік і відображає усі вимоги регулюючих організацій, а саме:

- управління продажами страхових продуктів;

- управління портфелем договорів прямого страхування та співстрахування, супровід усіх типів договорів;

- побудова графіків платежів;

- управління фінансами та грошовими коштами, збитками тощо.

На рисунку 1 продемонстровано інтерфейс даного програмного продукту.

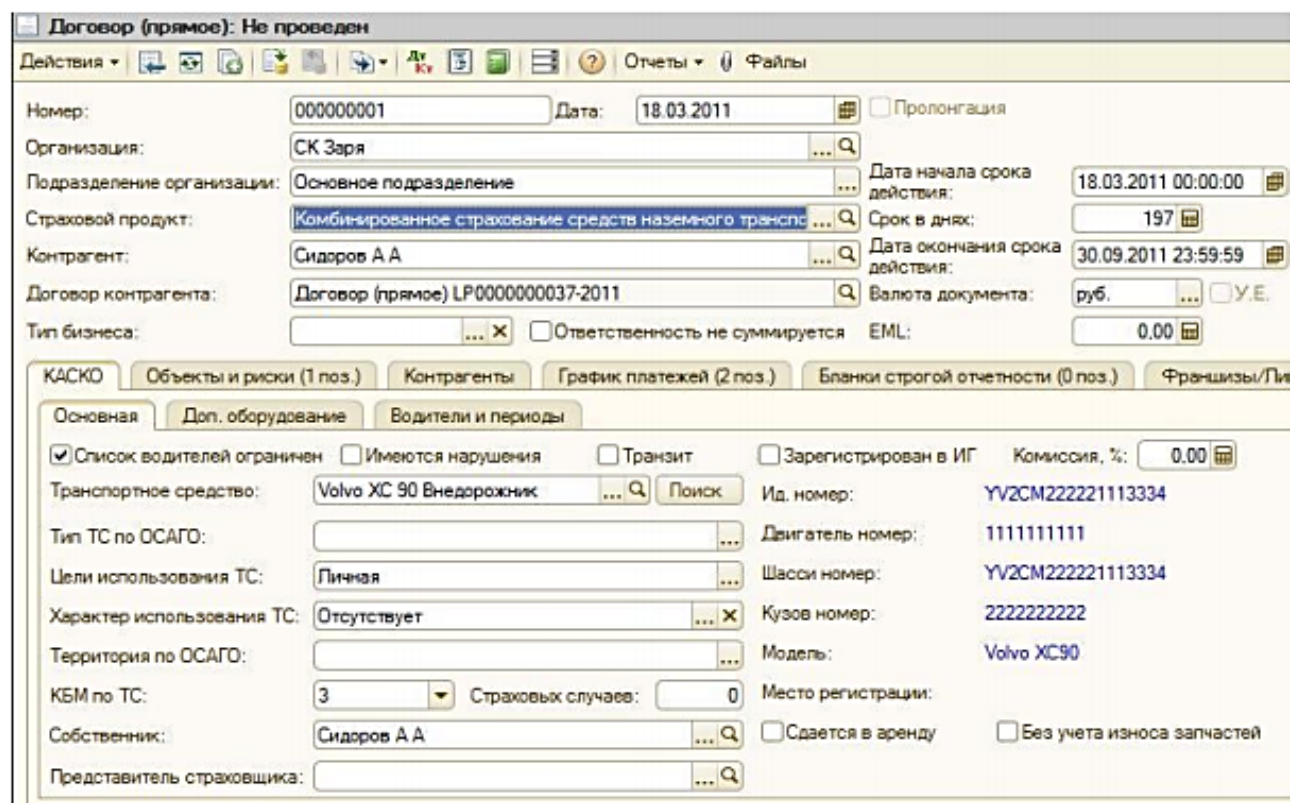

Рис. 1 Інтерфейс програми «1С: Підприємство 8. Страхова компанія 8 КОРП», [6].

Як видно 3 рисунка 1, інтерфейс програми зручний, що є значною перевагою. В одному вікні програми користувач може заповнити всю необхідну інформацію про клієнта, заповнити дані про транспортний засіб (якщо мова йде про КАСКО, наприклад), розрахувати графік платежів, ознайомитися з франшизою і т. д.

Але у даної системи є такі недоліки: немає можливості автоматизації оплати за діяльність страхових посередників, не існує можливості реєстрації настання страхових випадків, нема інструментів для оцінки ризику, визначення тарифів та умов страхування [6].

«Корпорація Парус» - компанія розробників, яка займається автоматизацією інформаційноаналітичних систем для бізнесу, державного та муніципального управління [10].
«Парус Страхування» - одна із найбільших комплексних програм, у складі якої є такі основні модулі: управління фінансами організації, страхування майна та відповідальності, перестрахування, аналіз результатів діяльності, облік і т.д. Усі модулі дозволяють проводити комплексну автоматизацію бізнес-процесів страхової компанії - користувача системи [8].

«Парус Страхування» дозволяе побудувати корпоративну інформаційну систему великомасштабної страхової компанії, яка поєднує центральний офіс і віддалені філіали. Оскільки «Парус Страхування» $\epsilon$ програмою комплексної автоматизації страхової діяльності, то вона має такі особливості:

- охоплення найважливіших функцій підрозділів фірми (керівництво, планово - 
економічна, актуарні й аналітична підрозділи, страхові та перестрахові відділи, виплата страхових відшкодувань);

- варіативність реалізації функцій управління за рахунок використання різноманітних алгоритмів (до 20) та моделей;

- повна автоматизація бізнес-процесів.

Програма «Парус Страхування» містить також такі функціональні модулі: облік персоналу та штатний розпорядок, розрахунок заробітної плати, бухгалтерський облік, ОСАГО, страхування осіб, що виїжджають закордон, , аналіз ы облік, управління діловими процесами, адміністрування [6].

Принципом модульності досягається гнучка комплектація, можливість поетапного впровадження та нарощування i розширення системи. Використання єдиної бази даних (БД) дозволяє спільно працювати великому числу користувачів і виконувати свої службові обов'язки.

Офіс і філії територіально не залежать одне від одного. Архітектура клієнт-сервер працює за принципом: клієнт посилає запит на сервер, який обробляє запити інших клієнтів і на основі аналізу видає відповідь. Сервер має більшу потужність і продуктивність, ніж клієнтський комп'ютер, тому обробка даних відбувається швидше i не відбувається порушення цілісності інформації.

Стабільність роботи страхових компаній безпосередньо залежить від безпеки IC, тому керівники висувають серйозні вимоги до захисту даних. Кожному працівнику надаються індивідуальні права і доступ до функцій системи. А інтеграція програми 3 операційними системами фірми «Microsoft» надає переваги за вартістю системи, розширення можливостей налаштувань форм вихідних документів, спрощується процес упровадження для співробітників [10].

Наступна програма - «АДС: Управління центром страхування 8», комплексна, тобто автоматизуе всі основні процеси страхової діяльності, включаючи ОСАГО. У набір завдань, що виконуються за його допомогою, входять: заповнення анкети та заявки на страхування, облік договорів страхування та бланків суворої звітності, автоматизація дій по ОСАГО, облік комісіі, розрахунки зі страхувальниками, надання можливості укладати договори 3 електронним підписом, здійснення смс-розсилок, робота поштового клієнта та інше [8].

Порівняння функціональної повноти «1С: Підприємство 8. Страхова компанія 8 КОРП» $\mathrm{i}$ «АДС: Управління центром страхування 8» представлена в Таблиці 2.

Таблиия 2

Функціональна повнота системи ««АДС: Управління центром страхування 8»

\begin{tabular}{|c|c|c|c|}
\hline \multirow[t]{2}{*}{ Критерій } & \multirow[t]{2}{*}{ Опис } & \multicolumn{2}{|c|}{ Наявність } \\
\hline & & $\langle 1 \mathrm{C}: \ldots .\rangle$. & «АДС...» \\
\hline Андерайтинг & $\begin{array}{l}\text { Інструменти для оцінки ризиків, визначення тарифів та } \\
\text { умов страхування }\end{array}$ & - & + \\
\hline Супровід договорів & Укладення, перестрахування, закриття, переогляд & - & + \\
\hline Облік договорів & $\begin{array}{l}\text { Відстеження укладених договорів (як закритих, так і } \\
\text { актуальних) }\end{array}$ & + & + \\
\hline $\begin{array}{c}\text { Робота за страховими } \\
\text { виплатами } \\
\end{array}$ & $\begin{array}{llll}\text { Реєстрація настання страхових } & \text { випадків, виплата } \\
\text { відшкодувань } & & \\
\end{array}$ & - & + \\
\hline $\begin{array}{c}\text { Облік страхових } \\
\text { виплат } \\
\end{array}$ & $\begin{array}{l}\text { Відстеження страхових випадків, що вже сталися та їх } \\
\text { статусу }\end{array}$ & + & + \\
\hline $\begin{array}{c}\text { Робота зі страховими } \\
\text { резервами }\end{array}$ & Автоматизація розрахунків страхових резервів фірми & + & - \\
\hline $\begin{array}{c}\text { Взаєморозрахунки за } \\
\text { страховими } \\
\text { посередниками }\end{array}$ & $\begin{array}{lccc}\text { Автоматизація } & \text { розрахунків } & \text { зі } & \text { страховими } \\
\text { посередниками і управління їх діяльністю } & \end{array}$ & - & + \\
\hline $\begin{array}{c}\text { Розрахунок } \\
\text { комісійних винагород }\end{array}$ & $\begin{array}{l}\text { Автоматизація оплати за діяльність страхових } \\
\text { посередників }\end{array}$ & - & + \\
\hline $\begin{array}{l}\text { Ведення клієнтської } \\
\text { бази }\end{array}$ & $\begin{array}{l}\text { Ведення бази клієнтів } 3 \text { необхідним для супроводу } \\
\text { договорів інформації про них }\end{array}$ & + & + \\
\hline Бухгалтерія & $\begin{array}{l}\text { Ведення бухгалтерської діяльності і стандартного бух. } \\
\text { обліку }\end{array}$ & + & - \\
\hline
\end{tabular}

*Джерело: складено авторами за даними [6].

Таким чином, виходячи 3 даних Таблиці 2, можемо зазначити те, що функціонал системи «АДС: Управління центром страхування 8» більш ширший, ніж «1С: Підприємство 8. Страхова компанія 8 КОРП». 
Відповідно до проведеного дослідження можемо дати методи та напрямки розвитку інформаційних систем у страхових фірмах, а caмe:

- зосередження на розширенні функціоналу системи (можливість додаткового ведення бухгалтерії, клієнтської бази тощо);

- упровадження додаткового захисту бази даних, оскільки стабільна робота страхової компанії залежить також від безпеки системи;

- продовження роботи над оперативністю системи та їі масштабованістю.

Висновки. Підбиваючи підсумки даного дослідження, зазначимо, що інформаційна система - це складна система (середовище), структурними елементами якої $є$ інформація, людина, засоби комунікації тощо, а основними функціями - обробка, зберігання, подання та передача значних потоків інформації, допомога у прийнятті управлінських рішень. Інформаційні системи мають дещо полегшити функціонування страхових компаній, автоматизуючи деякі процеси в їх діяльності.
Але перш ніж вводити у використання IC, необхідно «підготувати» страхову фірму до цього: усі робочі процеси повинні бути ретельно налагоджені, документально оформлені у вигляді правил та інструкцій, повинно бути обдумано, хто і як підписує поліси від імені компанії, як проводяться розрахунки з брокерами тощо.

На сьогодні найбільш популярними інформаційними системами у страхових компаніях $\epsilon$ : «Парус-страхування», «1C: Підприємство 8. Страхова компанія 8 КОРП» i «АДС: Управління центром страхування 8 »-усі вони містять широке коло функцій та можливість для виконання завдань накшталт супроводу договорів, роботи за страховими виплатами, із посередниками, ведення обліку і т.д.

Таким чином, введення інформаційних системи та покращення (розширення) їх функціоналу $\epsilon$ основною покращення роботи страхових компаній та надання страховиками послуг.
1. Грицунов О.В. Інформаційні системи та технології: навч. посіб. Харків: ХНАМГ, 2010. 222 с.

2. Шевчук І. Б. Лекції з прикладних інформаційних систем. Львів, 2018. $11 \mathrm{c.}$

3. Павленко П. М., Філоненко С. Ф., Бабіч К.С. та ін. Інформаційні системи та технології: навч. посіб. К. : HAУ, 2013. 324 c.

4. Ушакова О. І., Плеханова Г. О. Лекції 3 інформаційних систем та технологій на підприємстві. Харків: Вид. ХНЕУ, 2009. 128 с.

5. Неізвестна О. В., Огоновська А. О. Інформаційне забезпечення менеджменту страхової діяльності // Вісник Мукачівського державного університету. 2017. Вип. 10. С. $643-650$.

6. Хитрова Т. И., Хитрова Е. М. Информационные технологии в страховании: учеб. пособие. Иркутск: БГУ, 2019. 96 с.

\section{References}

1. Hrytsunov, O. V. (2010), Informatsiyni systemy ta tekhnolohiy [Information systems and technologies], KHNAMG, Kharkiv.

2. Shevchuk, I. B. (2018), Lektsiyi z prykladnykh informatsiynykh system [Lectures on applied information systems], Lviv.

3. Pavlenko, P. M., Filonenko, S. F., Babich, K. S. (2013), Informatsiyni systemy ta tekhnolohiy [Information systems and technologies], NAU, Kyiv.

4. Ushakova, O. I., Plekhanova, G. O. Lektsiyi z informatsiynykh system ta tekhnolohiy na pidpryyemstvi [Lectures on information systems and technologies at the enterprise], Vid, Kharkiv.

5. Nieizviestna, O. V., Ohonovska, A. O. (2017), "Information support of insurance management", Visnyk
Mukachivs'koho derzhavnoho universytetu, no 10, pp. 643 -650 .

6. Khitrova, T. I., Khitrova, E. M. (2019), Informatsionnyye tekhnologii v strakhovanii [Information technology in insurance], BGU, Irkutsk.

7. Ivankova, A. V. (2019), "Development of an information system for an insurance company", Abstract of student's dissertation, Applied Informatics, Saratov national research state university named after N.G. Chernyshevsky, Saratov, Russia.

8. Dmitriieva, Yu. Yu. (2015), "IT solutions for insurance companies", Nauchnyye zapisi molodykh issledovateley, no 6, pp. $31-35$.

9. Stiepura, M. A. (2020), "The use of information technology in the economy", Elektronnyy nauchnyy zhurnal «Dnevnik nauki», no 1,7 p. 
10. Simonova, E. I. (2016), "Designing an information system for a branch of the insurance joint-stock company "Nadezhda"”, SFU, Krasnoyarsk, available at: http://elib.sfu-kras.ru/handle/2311/29092 (Accessed 20. 11. 2020).

Аннотация

Инна Киселёва, Гоар Геворгян

\section{ФУНКЦИОНИРОВАНИЕ ИНФОРМАЦИОННЫХ СИСТЕМ И ТЕХНОЛОГИЙ В СТРАХОВАНИИ}

Рассмотрено понятие «информационные системыл", «информационные технологии», проанализированы наиболее актуальные информачионные системы, которые используются страховыми компаниями Украины. Целью данного исследования является обзор и анализ информационных систем Украины для предложения более эффективных видов информачионных систем и улучшения состояния страхового рынка страны в иелом и деятельности страховых компаний в отдельности.

Ключевые слова: информационные системы, технология, страхование, страховая компания, страховщик, страхователь.

\section{Summary}

Inna Kisileva, Goar Gevorgyan

\section{FUNCTIONING OF INFORMATION SYSTEMS AND TECHNOLOGIES IN INSURANCE}

In this article, the authors considered the concepts of "information system" and "information technology", studied the interpretation of these concepts by other scientists and, as a result, managed to give their own definition of the above terms. The purpose of this study is to review and analyze information systems in Ukraine to offer more efficient types of information systems and improve the state of the insurance market in the country as a whole and the activities of insurance companies separately.

As a result of the analysis of various sources, it was possible to formulate requirements for information technologies and systems, among which the most important are: automation of processes in an insurance company, assistance with various calculations, ease of interface and use, additional functions such as accounting, etc. We managed to identify the three most common systems, compare them with each other and indicate the advantages and disadvantages of each of them. It is also important that before introducing information systems into their activities, it is necessary to prepare the insurer for this: to develop instructions and rules for working with the system, to establish workflow, to distribute responsibilities between employees.

Thus, in the modern world, insurance companies urgently need to implement information systems and technologies in their activities, because they are "assistants" in working with clients, greatly simplify the processes associated with insurance, affect the company's competitiveness, and help its development.

And, to summarize, the development of information technologies in the insurance industry is still not over and companies continue to work on improving existing systems and developing new systems, focusing on market requirements, among which the authors highlighted: scaling of information systems, expanding the functionality of programs, simplifying the interface, etc.

Keywords: information systems, technology, insurance, insurance company, insurer, policyholder. 